\title{
ANALYZING THE ROLE OF EMPOWERMENT IN MEDIATING EFFECT OF KNOWLEDGE MANAGEMENT ON OCB
}

\author{
By: \\ Rita Aryani ${ }^{1)}$ \\ W. Widodo ${ }^{2)}$ \\ ${ }^{1)}$ Pancasakti College of Teachers Training and Education, Bekasi, Indonesia \\ ${ }^{2)}$ Faculty of Education and Social Sciences of Indraprasta PGRI University \\ Jakarta, Indonesia \\ E-mail: \\ ritaar1757@gmail.com
}

\begin{abstract}
This study analyzes the effect of knowledge management on organizational citizenship behavior (OCB) mediating by empowerment. The research data was collected by a questionnaire through the survey methods toward 375 teachers. Data analysis uses path analysis supported by descriptive statistics. The results show that knowledge management had a significant effect on OCB mediating by empowerment. Thus, the teacher's OCB can be improved through knowledge management and empowerment. This finding can be discussed as a reference among researchers and practitioners to develop better models of OCB in the future and various contexts of organizations.
\end{abstract}

Keywords: knowledge management, empowerment, OCB

\section{A. INTRODUCTION}

The existence of OCB very important and vital for the organization, especially non-profit organizations, such as educational organizations. Several studies concluded that OCB can be enhancing employee performance (Hidayah \& Harnoto, 2018) and productivity (Barsulai, Makopondo, \& Fwaya, 2019) which then has implications for organizational performance (Aval, Haddadi, \& Keikha, 2017). However, in reality, the teachers' OCB in Indonesia, particularly at Jakarta, Banten, and West Java provinces, have not shown conditions conducive to supporting their performance and school organization. The indications, among others, are that the teacher does not show extra efforts to improve student achievement and the quality of school and education. For example, the teachers have not altruism, conscientiousness, sportsmanship, courtesy, and civic virtue to help students increase their academics achievement, especially students who have difficulty following lessons and have low academic achievement. Based on the urgently, these studies aim to explore teacher's OCB by knowledge management and empowerment perspective. 
OCB related to employee behavior that is beyond the call of duty, exceeds formal job duties, such as cooperation and helpfulness to others that support the organization's social and psychological context, but is often necessary for the organizational survival (Kreitner \& Kinicki, 2012; McShane \& Von Glinow, 2015). OCB is individual behavior that is not regulated by the organization, and that reward systems are not formally calculated, for example, to help a colleague, to work overtime if needed, but this behavior will drive the effectiveness and efficiency of the overall functioning of the organization (Peleașă, 2018; Spitzmuller, van Dyne, \& Ilies, in Hanafi, Soebyakto, \& Afriyanti 2018). OCB includes feedback that may promote employees those behaviors which make them good citizens of an organization. In turn, these citizenship behaviors may instigate the employees to put extra effort into the implementation process (Haider, Heredero, \& Botella, 2017). According to Arifin, Herri, and Puteri (2019), OCB can be implemented in the aspects of altruism, conscientiousness, sportsmanship, courtesy, and civic virtue.

\section{B. LITERATURE REVIEW}

\section{Knowledge Management and OCB}

Knowledge management is the concept that arose approximately two and a half decades who organizing information and knowledge holistically (Khanal \& Poudel, 2017). The leveraging of knowledge proved influences what people do at work and how organizations understand and use the term "knowledge" shapes how knowledge, including knowledge in data form, is shared through various communication regimes (such as the firm intranet or eCenter) and learning methodologies in the workplace (Garrick \& Chan, 2017). But, many scholars also argue that knowledge resides in man's mind and cannot be easily identified or transferred from one person to another. It is believed to lie in the experiences, beliefs, values, and culture of a person or an organization. Knowledge is a specific property of people or organizations and is seldom copied by others. Such knowledge provides a competitive advantage for the individual and the firm (Torabi, Kyani, \& Falakinia, 2016). That is what encourages the study of knowledge management to remain important today. According to Noe et al. (2015), the process of enhancing company performance can caries out by using tools, processes, systems, and cultures to improve the creation, sharing, and use of knowledge. That means that knowledge management is the managing of knowledge (including technology) owned by the organization in ways that are acceptable to members of the organization to provide optimal benefits for improving the quality of the organization and all its members.

Davenport, as a quote Widodo, Suendarti, and Hasbullah (2020), identified ten principles of knowledge in which emphasizes the people, process, and conceptual aspects of knowledge management. The people principles related to the recognition that implementation of knowledge management is very political for found a person to be the official knowledge managers for an organization, that using knowledge and sharing it is not easy or natural, and knowledge management requires hybrid solutions of people and technology. The process principles 
recognize that knowledge management involves improving or transforming existing knowledge work processes, providing people with access to knowledge is only the beginning of knowledge management, and that knowledge management is never finished because knowledge is constantly changing and evolving. The conceptual principles recognize that knowledge management is very expensive, requires a knowledge contract, an inherent recognition of the thorny concept of intellectual property. These principles can be conditioned to potentially stimulate various behavior reflected OCB, such as altruism, conscientiousness, sportsmanship, courtesy, and civic virtue (Arifin, Herri, \& Puteri, 2019). The research conducted by Lin and Hsiao (2014) also indicated that knowledge management affects OCB. Based on argues and studies above, the first hypothesis in this study is:

\section{$\mathrm{H}_{1}$ : Knowledge management had a direct effect on OCB.}

\section{Empowerment and OCB}

The scholar gives various definitions of empowerment based on their perspective. For example, Ivancevich, Konopaske, and Matteson (2014) state that empowerment is sharing power and authority with subordinates to increase their confidence and effectiveness. For Rue, Ibrahim, and Byars (2016), empowerment relates to the form of decentralization that involves giving subordinates substantial authority to make decisions. Meanwhile, Newstrom (2015) argues that empowerment refers to any process that provides greater autonomy to employees through the sharing of relevant information and the provision of control over factors affecting job performance. Besides, from a psychological perspective, empowerment is employees' belief in the degree to which they affect their work environment, their competence, the meaningfulness of their job, and their perceived autonomy in their work (Robbins \& Judge, 2015). Empowerment consists of four indicators, namely building a relationship, build communication, involved in problem-solving, and reflects the attitudes and values of the profession (Dubois \& Miley, 2011). These indicators if in good condition can increase OCB manifested in altruism, conscientiousness, sportsmanship, courtesy, and civic virtue (Arifin, Herri, \& Puteri, 2019). Several studies carried out by Yangaiya and Abubakar (2015), Cheasakul and Varma (2016), Goksoy (2017), Shahab, Sobari, and Udin (2018), Jayarathna (2019), and Tindowen (2019) also revealed that empowerment influences OCB. Based on the statements and studies above, the first hypothesis in this study is:

\section{$\mathrm{H}_{2}$ : Empowerment had a direct effect on OCB.}

\section{Knowledge Management and Empowerment}

Empowerment besides influences OCB is also affected by knowledge management. The principles of knowledge management which emphasize the people, process, and conceptual (Davenporf, in Widodo, Suendarti, \& Hasbullah, 2020) if in conducive conditions potentially stimulating empowerment, manifested in building a relationship, build communication, involved in problem-solving, and reflects the attitudes and values of the profession (Dubois \& Miley, 2011). The 
research result by Badah (2012), Haghighi, Tabarsa, and Kameli (2014), Hasani and Sheikhesmaeili (2016), Zolfaghari, Ghorsi, and Dehestani (2017), and Asadollahzadeh (2018) also indicate that knowledge management affects empowerment. Based on states and studies above, the third hypothesis in this study is:

$\mathrm{H}_{3}$ : Knowledge management had a direct effect on empowerment.

\section{Knowledge Management and OCB Mediating by Empowerment}

The various studies above showed that empowerment mediates the effect of knowledge management on OCB. If the principles of knowledge management which are emphasized on the people, process, and conceptual (Davenporf, in Widodo, Suendarti, \& Hasbullah, 2020) in conducive conditions can be stimulating empowerment among teachers actualized in building a relationship, build communication, involved in problem-solving, reflects the attitudes and values of the profession (Dubois \& Miley, 2011). That it then implicates improving OCB in daily activities such as altruism, conscientiousness, sportsmanship, courtesy, and civic virtue (Arifin, Herri, \& Puteri, 2019). The studies carried out by Hasani and Sheikhesmaeili (2016), Zolfaghari, Ghorsi, and Dehestani (2017), and Asadollahzadeh (2018) also indicate that knowledge management influences empowerment, meanwhile the research conducted by Yangaiya and Abubakar (2015), Cheasakul and Varma (2016), Goksoy (2017), Shahab, Sobari and Udin (2018), Jayarathna (2019), and Tindowen (2019) show that empowerment affects OCB. Based on argues and studies above, the fourth hypothesis in this study is:

$\mathrm{H}_{4}$ : Knowledge management had an indirect effect on OCB mediating by empowerment.

\section{METHODS}

This research conducted uses a quantitative approach to the survey method through a questionnaire in the form of a Likert scale model with five alternative answers: strongly disagree, disagree, neutral, agree, and strongly agree. The questionnaire was made by researchers themselves based on the theoretical dimensions of the experts. The knowledge management questionnaire consists of 10 items with an alpha coefficient $=0,938$, empowerment consists of 10 items with an alpha coefficient $=0,908$, and OCB consists of 9 items with alpha coefficients $=$ 0,923 .

The participant of research is 375 teachers in Indonesia spread across three provinces (Jakarta, Banten, West Java) determined by accidental sampling based on participant willingness to fill in the questionnaire at the time the research was conducted (Widodo, 2019).

Data analysis by path analysis and to test the significance of the path coefficient uses a t-test supported by correlational and descriptive statistics. Descriptive analyzes were performed by SPSS version 22, while the path analysis by Lisrel 8,80. 


\section{RESULT AND DISCUSSION}

\section{Result}

The profile of the research participant as respondent presented in Table 1. The majority of gender is female (64\%), ages 26 - 35 years $(42.13 \%)$, bachelor education $(74.93 \%)$, marital status $(76 \%)$, and length of teaching $\leq 5$ years $(33,33 \%)$.

Table 1.

Profile of Research Participant

\begin{tabular}{lcc}
\hline \multicolumn{1}{c}{ Profile } & Amount & Percentage \\
\hline Gender & & \\
1. Male & 135 & 36 \\
2. Female & 240 & 64 \\
Age & & \\
1. $\leq 25$ Year & 48 & 12.80 \\
2. 26-35 Year & 158 & 42.13 \\
3. 36-45 Year & 90 & 24 \\
4. 46-55 Year & 77 & 20.53 \\
5. $\geq 56$ Year & 2 & 0.53 \\
Education & & \\
1. Diploma (D3) & 6 & 1.60 \\
2. Bachelor (S1) & 281 & 74.93 \\
3. Postgraduate (S2) & 88 & 23.47 \\
Status & & \\
1. Married & 285 & 76 \\
2. Unmarried & 90 & 24 \\
Length of Teaching & & \\
1. $\leq 5$ Year & 125 & 33.33 \\
2. 6-10 Year & 90 & 24 \\
3. 11 - 15 Year & 59 & 15.73 \\
4. $\geq 16$ Year & 101 & 26.93 \\
\hline
\end{tabular}

The results of the descriptive statistical analysis for the three research variables are presented as followed in Table 2. The mean values of the three variables from the lowest to the highest in succession are OCB (35.04), empowerment (40.56), and knowledge management (43.19).

Table 2.

\section{Descriptive Statistics}

\begin{tabular}{ccccc}
\hline & & $\begin{array}{c}\text { KNOWLEDGE } \\
\text { MANAGEMENT }\end{array}$ & EMPOWERMENT & \multirow{2}{*}{ OCB } \\
\hline \multicolumn{1}{c}{$\mathrm{N}$} & Valid & 375 & 375 & 375 \\
& Missing & 0 & 0 & 0 \\
Mean & & 43.19 & 40.56 & 35.04 \\
Median & & 43.00 & 40.00 & 35.00
\end{tabular}




\begin{tabular}{lccc} 
Mode & 40 & 40 & 36 \\
Std. Deviation & 5.232 & 4.751 & 5.627 \\
Variance & 27.371 & 22.568 & 31.661 \\
Range & 31 & 24 & 32 \\
Minimum & 19 & 26 & 13 \\
Maximum & 50 & 50 & 45 \\
Sum & 16195 & 15210 & 13141 \\
\hline \multicolumn{4}{c}{}
\end{tabular}

The results of hypothesis testing with path analysis of the effects of knowledge management on OCB mediating by empowerment are summarized in Table 3 and visualized in Figure 1 and Figure 2. All of the hypotheses were supported ( $\mathrm{t}_{\text {value }}>\mathrm{t}_{\text {table }}$ at $\alpha=0,01$ ). Therefore the result of this study revealed that knowledge management had a significant direct effect on OCB, empowerment had a significant direct effect on $\mathrm{OCB}$, and knowledge management had a significant indirect effect on OCB mediating by empowerment.

In Figure 1 and Figure 2, the test results of the model with the goodness of fit statistics show the significant with Chi-Square $=0.000, \mathrm{df}=0, \mathrm{p}_{\text {value }}=1,00000$ $>0,05$ and RMSEA $=0,000<0,08$. That means the model tested is fit. This result indicates that the theoretical model being tested is supported by empirical data from teachers in Indonesia, especially in three provinces (Jakarta, Banten, West Java).

Table 3.

Summary of Path Coefficients and $\mathbf{t}_{\text {value }}$

\begin{tabular}{lccc}
\hline \multicolumn{1}{c}{ Hypothesis } & Path Coefficients & $\mathbf{t}_{\text {Value }}$ & $\begin{array}{c}\text { Hypothesis } \\
\text { Testing }\end{array}$ \\
\hline $\begin{array}{l}\mathrm{H}_{1}: \text { Knowledge Management }(\mathrm{X}) \text { on OCB } \\
\quad\left(\mathrm{Y}_{2}\right)\end{array}$ & $.24 * *$ & 6.50 & Supported \\
$\mathrm{H}_{2}:$ Empowerment $\left(\mathrm{Y}_{1}\right)$ on OCB $\left(\mathrm{Y}_{2}\right)$ & $.63 * *$ & 16.98 & Supported \\
$\begin{array}{l}\mathrm{H}_{3}: \text { Knowledge Management }(\mathrm{X}) \text { on } \\
\text { empowerment }\left(\mathrm{Y}_{1}\right)\end{array}$ & $.37 * *$ & 7.74 & Supported \\
$\begin{array}{l}\mathrm{H}_{4}: \text { Knowledge Management }(\mathrm{X}) \text { on } \mathrm{OCB}^{*} \\
\quad\left(\mathrm{Y}_{2}\right) \text { mediating by empowerment }\left(\mathrm{Y}_{1}\right)\end{array}$ & $.23 * *$ & 7.04 & Supported \\
\hline$* * \mathrm{p}<.01$ & & &
\end{tabular}

Source: processed data

\section{Discussion}

The result of this research revealed that knowledge management had a significant effect on OCB, either directly or indirectly mediating by empowerment. The research also created a fit model that the theoretical model was following (fit) with empirical data from the teachers in Indonesia, especially from the province of DKI Jakarta, West Java, and Banten. This finding confirms that knowledge management and empowerment are important determinants for the teacher's OCB. Moreover, empowerment plays a significant role as a mediator of the effect of knowledge management on OCB. These findings were in line, consistent, and confirmed other studies and research results used as a reference to develop this research hypothesis. For example, several studies concluded that OCB influenced 
by knowledge management (Lin \& Hsiao, 2014) and empowerment (e.g. Yangaiya \& Abubakar, 2015; Cheasakul \& Varma, 2016; Goksoy, 2017; Shahab, Sobari \& Udin, 2018; Jayarathna, 2019; Tindowen, 2019). As a consequence of this evidence, school leaders urgent to manage knowledge management and empowerment better through various policies, approaches, methods, and strategies that are relied on to develop the teacher's OCB. In the case of knowledge management, the school leaders should be facilitated and stimulated upholding the principles of knowledge management which is emphasized on the people, process, and conceptual. For empowerment context, school leaders should be facilitated to the growth of relationships, communication, problem-solving, attitudes, and values of professionalism among teachers.

Besides that, the results of this study also found that empowerment plays an important role as mediators of the effect of knowledge management on OCB. This evidence in line with studies concluded that knowledge management affects empowerment (e.g. Hasani \& Sheikhesmaeili, 2016; Zolfaghari, Ghorsi, \& Dehestani, 2017; Asadollahzadeh, 2018), empowerment affects OCB (e.g. Yangaiya \& Abubakar, 2015; Cheasakul \& Varma, 2016; Goksoy, 2017; Shahab, Sobari \& Udin, 2018; Jayarathna, 2019; Tindowen, 2019), and knowledge management affects OCB (Lin \& Hsiao, 2014). This finding reveals empirical facts that the existence of empowerment very important and urgent to be considered in the context of improving teacher's OCB through knowledge management. That is, any efforts to increase teacher's OCB will be better if done through improving knowledge management with support improving empowerment. This has the consequence that school leaders urgent to develop optimally empowerment through various possible approaches, methods, and strategies.

Overall, the results of this study confirm the results of several studies in various countries, industrial, occupational sectors, and organizations and find an empirical model of the effect of knowledge management on OCB mediating by empowerment based on the data from teachers in Indonesia. This model can be discussed as a discourse or reference among researchers and practitioners to develop better models of OCB in the future and various contexts of organizations.

\section{E. CONCLUSION}

This research proves that knowledge management had a significant effect on teacher's OCB, either directly or indirectly mediated by empowerment. This study also was found a fit research model about the effect of knowledge management on OCB mediating by empowerment with the research field of the teachers in Indonesia, particularly, at DKI Jakarta, West Java, and Banten province. This model can be discussed among researchers and practitioners as references/discourse or a strategy for developing OCB in various contexts and research fields. For the researcher, the model can be further expanded into new research with more participants, adding variables, other indicators, and another statistical approach, such as structural equation modeling (SEM). For practitioners, the model can use to increase the OCB of teachers or employees through improving knowledge management and empowerment. 


\section{REFERENCES}

Arifin, M., Herri, H., \& Puteri, H. (2019). Personality, grit, and organizational citizenship behavior at vocational higher education: The mediating role of job involvement. Journal of Social Studies Education Research, 10(2), 168-187.

Asadollahzadeh, F. (2018). The effect of knowledge management on the empowerment of Youth and Sports General Directorate of Mazandaran province. Research \& Investigations in Sports Medicine, 3(5), 215-221

Aval, S. M., Haddadi, E., \& Keikha, A. (2017). Investigating the effect of organizational citizenship behavior (OCB) components on organizational agility. Interdisciplinary journal of education, 1(1), 59- 67.

Badah, A.M. (2012). Relationship between the knowledge management processes and the administrative empowerment with the employees of The Ministry of Higher Education and Scientific Research - Jordan. European Scientific Journal, 8(28), 191-209.

Barsulai, S. C., Makopondo, R.O.B., Fwaya, E.V.O. (2019). The effect of organizational citizenship behavior on employee productivity in star-rated hotels in Kenya. European Journal of Hospitality and Tourism Research, 7(1), 1-8.

Byars, L. L., Rue, L.W., \& Ibrahim, N.A. (2016). Human resource management, $11^{\text {th }}$ ed., New York: McGraw-Hill Education.

Cheasakul, U., \& Varma, P. (2016). The influence of passion and empowerment on organizational citizenship behavior of teachers mediated by organizational commitment. Contaduría y Administración, 61(3), 422-440.

DuBois, B. L., \& Miley, K. K. (2011). Social work: An empowering profession. $7^{\text {th }}$ Edition. Boston: Pearson.

Garrick, J., \& Chan, A. (2017). Knowledge management and professional experience: the uneasy dynamics between tacit knowledge and performativity in organizations. Journal of Knowledge Management, 21(4), 872-884.

Goksoy, A. (2017). The role of psychological empowerment and organizational citizenship behaviors on employee resistance to change. European Journal of International Studies, 7, 1-9.

Haghighi, M. A., Tabarsa, G.A., \& Kameli, B. (2014). Investigation of the relationship between knowledge management processes and the empowerment of human resources. Global Journal of Management Studies and Researches, 1(2), 122-130.

Hanafi, A., Soebyakto, B. B., \& Afriyanti, M. (2018). The effect of organizational citizenship behavior (OCB) and quality of work-life (QWL) on employee work performance with motivation as an intervening variable at the industrial affairs of South Sumatera Province. International Journal of Scientific Research and Management (IJSRM), 06(09), EM-2018-676-685. 
Hasani, K., \& Sheikhesmaeili, S. (2016). Knowledge management and employee empowerment: A study of higher education institutions. Kybernetes, 45(2), 337-355.

Hidayah, S., \& Harnoto. (2018). Role of organizational citizenship behavior (OCB), perception of justice, and job satisfaction on employee performance. Jurnal Dinamika Manajemen, 9(2) 2018, 170-178

Ivancevich, J. M., Konopaske, R., \& Matteson, M. T. (2014). Organizational behavior \& management, tenth edition. New York: McGraw-Hill Education.

Jayarathna, S.M.D.Y. (2019). Impact of transformational leadership on organizational citizenship behavior (OCB): Mediating effect of psychological empowerment: A study on apparel sector Sri Lanka. Journal of Business School, 2(4), 1-15.

Khanal, L., \& Poudel, S.R. (2017). Knowledge management, employee satisfaction, and performance: empirical evidence from Nepal. Saudi Journal of Business and Management Studies, 2(2), 82-91

Kreitner, R. \& Kinicki, A. (2012). Organizational behavior. New York: McGrawHill International Edition.

Lin, R. S., \& Hsiao, J. (2014). The Relationships between transformational leadership, knowledge sharing, trust, and organizational citizenship behavior. International Journal of Innovation, Management, and Technology, 5(3) 171-174.

McShane, S. L., \& Von Glinow, M.A. (2015). Organizational behavior: Emerging knowledge, global reality. 7th edition. United States: McGraw-Hill Education.

Peleașă, S. (2018). Grit utility in explaining the job and contextual performance. Studia Doctoralia Psychology and Educational Science, 9(15), 54-64.

Robbins, S. P., \& Judge, T. A. (2015). Organizational behavior. New Jersey: Pearson Education, Inc.

Shahab, M.A., Sobari, A., \& Udin, U. (2018). Empowering leadership and organizational citizenship behavior: The mediating roles of psychological empowerment and emotional intelligence in the medical service industry. International Journal of Economics and Business Administration, 6(3), 80-91.

Torabi, M.H. R., Kyani, A., \& Falakinia, H. (2016). An investigation of the impact of knowledge management on human resource performance in the management of Keshavarzi Bank Branches in Tehran. Procedia - Social and Behavioral Sciences, 230,471 - 481.

Tindowen, D.J. (2019). Influence of empowerment on teachers' organizational behaviors. European Journal of Educational Research, 8(2), 617-631. 
Widodo, W. (2019). Metodologi Penelitian Populer dan Praktis. Depok: Rajawali Pers.

Widodo, W., Suendarti, M., \& Hasbullah, H. (2020). Exploring the effect of knowledge management and social intelligence on the professional performance of mathematics teachers: A mediating by achievement motivation. Journal of Xidian University, 14(6), 749-757.

Yangaiya, S. A., \& Abubakar, A. (2015). Examining the relationship between empowerment and organizational citizenship behavior of secondary school teachers in Katsina State Nigeria. Proceeding of the 3rd Global Summit on Education, 468-475. Kuala Lumpur, Malaysia: World Conference Resources.

Zolfaghari, S., Ghorsi, M., \& Dehestani, R. (2017). Developing psychological empowerment through knowledge sharing behavior. International Journal of Economics, Commerce, and Management, V(6), 519-532. 